This item was submitted to Loughborough's Research Repository by the author.

Items in Figshare are protected by copyright, with all rights reserved, unless otherwise indicated.

\title{
Building climate resilience of UK's rail network through a multihazard approach
}

PLEASE CITE THE PUBLISHED VERSION

https://doi.org/10.1680/jensu.18.00031

PUBLISHER

(C) ICE Publishing

VERSION

AM (Accepted Manuscript)

\section{PUBLISHER STATEMENT}

This paper was accepted for publication in the journal Proceedings of the Institution of Civil Engineers Engineering Sustainability and the definitive published version is available at https://doi.org/10.1680/jensu.18.00031

\section{LICENCE}

CC BY-NC-ND 4.0

\section{REPOSITORY RECORD}

Green, Alex, and Ksenia Chmutina. 2019. "Building Climate Resilience of Uk's Rail Network Through a Multihazard Approach". figshare. https://hdl.handle.net/2134/36733. 


\author{
Building climate resilience of London's rail network through a multi-hazard approach \\ Alex Green ${ }^{1}$ and Ksenia Chmutina ${ }^{2 *}$ \\ ${ }^{1}$ Graduate Tunnel Engineer, Atkins, London, UK \\ ${ }^{2}$ School of Architecture, Building and Civil Engineering, Loughborough University, UK \\ *Corresponding author: k.chmutina@lboro.ac.uk
}

\begin{abstract}
Climate projections suggest the UK will be increasingly affected by climate-induced hazards in the future, exacerbating the potential for multi-hazard events to occur. This paper explores the extent to which climate resilience is being embedded in current and future rail transport infrastructure projects in London through use of a multi-hazard approach. It concludes that a multi-hazard approach is a relatively new concept and is therefore not currently being considered widely; however, opportunities for decision makers to explore its value to mitigate climate risks through collaborative working and further research exist - this paper recommends that two main stages are required to achieve this. Route 1 requires climate/hazard experts to identify and characterise the different hazard interactions that could occur, including their impact on the UK/London. Following this, Route 2 involves the creation of multidisciplinary workshops to identify any multi-hazard vulnerabilities associated with different rail assets potentially highlighting areas where further research is required. The paper concludes that although a London rail context has been adopted in order to understand the relevance of a multi-hazard approach, there is opportunity for it to be considered across many different sectors in the UK and the wider civil engineering industry.
\end{abstract}

Keywords: Climate Change; Infrastructure planning; Railway systems

\title{
1. Introduction
}

The anthropogenic nature of climate change is undeniable (IPCC, 2014) and various approaches to climate change mitigation and adaptation have been implemented in the UK. The adaptation efforts are largely connected with reducing climate-related risk, such as protecting critical infrastructure from extreme weather (ICE, 2009; Forzieri et al., 2018). Although the UK does not experience the effects of all climate-induced hazards, some - in particular floods and storms - pose a serious threat to the UK's economy, infrastructure, and population (Cabinet Office, 2011). The Climate Change Act 2008 and the Greater London Authority (GLA) Act 2007 specify the need for the UK/London to adapt to climate change, as a range of climate-induced hazards put London at great risk; infrastructure projects have the opportunity to take action through building resilience to key climate-induced hazards (e.g. extreme hot/cold temperatures) (Defra, 2011).

Climate change is projected to increase the frequency and severity of numerous weather events (ICE, 2017); therefore, the possibility of climate-induced hazards occurring simultaneously or cumulatively over time may rise, resulting in hazard interactions and exacerbating climate risk. National government guidance for infrastructure stakeholders mentions the use of an 'all-hazards approach' to resilience through considering the connection between different natural hazard events (Cabinet Office, 2011); 
however, the explicit focus to addressing multiple hazards simultaneously - and the tensions this may create - are lacking. The Sendai Framework for Disaster Risk Reduction (UNISDR, 2015) highlights the need for a multi-hazard approach to be used to mitigate disaster risk. As disaster risk reduction (DRR) and climate change adaptation (CCA) are inter-related rather than independent (Chmutina et al., 2017), there is a clear gap to explore the relevance of using a multi-hazard approach within the CCA-related scope of new infrastructure schemes.

This paper aims to identify whether and how decision makers are utilising a multi-hazard approach to address climate-induced hazards in order to build resilience of current and future rail transport infrastructure projects in London. The research focuses on London, where the predicted population growth of 37\% between 2011 and 2050 (GLA Intelligence, 2017) will increase the demand for critical infrastructure - specifically rail transport, which provides a vital network for people living and working across the city.

The paper reviews the projected changes in UK climate, and the impact the associated climate-induced hazards will have on London's rail network. The following sections define a multi-hazard approach, describe the methodology and discuss the importance of a multi-hazard approach to increase the climate resilience of rail infrastructure in London, providing conclusions and recommendations for decision makers.

\section{Literature Review}

\subsection{London's rail infrastructure network}

Across the UK, rail journeys have doubled in the last 20 years, and London residents are four times more likely to use rail compared to people living elsewhere in England (DfT, 2017). This is putting increasing demand on rail services, and is one of the primary reasons why new major rail lines such as High Speed Two (HS2) are currently being planned, designed and constructed (Hansford, 2016). London's rail network consists of several different services, including: London Underground, London Rail and National Rail. GLA, and specifically the Mayor of London, are the main driving forces behind CCA in London - a number of major policies were created to facilitate change across the city, e.g. Mayor's Transport Strategy (Davoudi et al., 2011).

\subsection{Climate-induced hazards in the context of London and rail infrastructure}

The climate projections (UKCP09) for a 'medium emissions scenario' for the 2080s in Southeast England are increase in: average daily mean temperature of $3-4^{\circ} \mathrm{C}$ (for summer and winter), winter mean precipitation of $10-30 \%$, and relative sea level of up to $30 \mathrm{~cm}$; as well as a decrease in summer mean precipitation of 20-30\% (Jenkins et al., 2009). UKCP09 considered average climates across winter and summer, and how these are likely to change. Although some predictions were produced for extreme values, such as summer maximum temperatures and rainfall on the wettest day of winter, these results were averaged over regional areas, over many decades (CCC, 2016). Despite efforts to overcome the complexities associated with predicting future weather (e.g. use of UKCP09 weather generator), there is limited information to suggest the possible variations in weather at a given location and time, and thus determine the extent of extreme weather changes. 
Rail infrastructure is susceptible to climate-induced hazards; this research has thus been undertaken to understand climate-related vulnerabilities within London's rail assets. Network Rail produces a 'Weather Resilience and CCA Plan' for each of its eight routes; the documents outline their weather-attributed Schedule 8 delay costs between 2006/07 and 2013/14, which refers to payments made by Network Rail to train operating companies (TOCs) for non-availability of timetabled train routes (Network Rail, 2014). For the South East, a clear increasing trend in the total amount of payments made due to extreme weather events over the time period studied emerged; snow accounted for the majority of delay costs between 2008 and 2011, with flooding and wind having the greatest impact in more recent years (Network Rail, 2014) - thus emphasising the importance of having a climate-resilient rail sector. Armstrong et al. (2017) highlight the need for the UK rail network to adapt the level of climate resilience of its infrastructure assets, through assessing the likely effect of climate change on the network and the current/future impacts of extreme weather.

The London Risk Register (LRP, 2016) categorises flooding, storms and gales, extreme cold, extreme heat, and drought as the most prominent climate-induced hazards for London; these impact both London and its rail infrastructure (Table 1).

Table 1. Effects of a range of climate-induced hazards on London and UK rail infrastructure

\begin{tabular}{|c|c|c|}
\hline $\begin{array}{c}\text { Climate- } \\
\text { induced } \\
\text { hazard }\end{array}$ & Impact on London & Impact on London's rail infrastructure \\
\hline Flooding & $\begin{array}{l}\text { - Sea level rise and increased } \\
\text { storminess will increase coastal flood } \\
\text { risk (IPCC, 2013) } \\
\text { - Increase in winter rainfall may } \\
\text { increase frequency/severity of } \\
\text { flooding (fluvial/pluvial) (Sayers et } \\
\text { al., 2015) } \\
\text { - Pluvial flood risk high due to city's } \\
\text { high building density and large paved } \\
\text { surface areas (Future of London, } \\
\text { 2016) }\end{array}$ & $\begin{array}{l}\text { Closure of line due to track flooding, } \\
\text { failure of lineside equipment due to } \\
\text { inundation of water, landslides due to } \\
\text { saturated embankments, and access } \\
\text { issues to depots, stations and offices } \\
\text { (Network Rail, 2015) }\end{array}$ \\
\hline $\begin{array}{l}\text { Storms and } \\
\text { gales }\end{array}$ & $\begin{array}{l}\text { - Projected heavy rain days (rainfall } \\
\text { greater than } 25 \mathrm{~mm} \text { ) will increase by } \\
\text { a factor of } 2-3.5 \text { in winter by } 2080 \text { s } \\
\text { (Murphy et al., } 2010 \text { ) }\end{array}$ & $\begin{array}{l}\text { - Falling trees and debris on overhead line } \\
\text { equipment and the track, resulting in } \\
\text { damage to rolling stock and asset failures } \\
\text { (Network Rail, 2015) } \\
\text { - High intensity rainfall leading to } \\
\text { embankment/earthwork instability, as soil } \\
\text { water content levels increase (Dawson et } \\
\text { al., 2016) }\end{array}$ \\
\hline $\begin{array}{l}\text { Extreme } \\
\text { cold }\end{array}$ & $\begin{array}{l}\text { - Winter 2010-2011 was UK's third } \\
\text { consecutive cold winter, resulting in } \\
\text { reduced rail services in/around } \\
\text { London (House of Commons, 2010) }\end{array}$ & $\begin{array}{l}\text { - Loss of power to rolling stock as a result } \\
\text { of contact failure due to the build-up of } \\
\text { snow and ice, and frozen or snow- } \\
\text { blocked switches (Network Rail, 2015) }\end{array}$ \\
\hline $\begin{array}{l}\text { Extreme } \\
\text { heat }\end{array}$ & $\begin{array}{l}\text { - London is prone to an 'urban heat } \\
\text { island (UHI) effect' (Oke, 1973; } \\
\text { Jenkins et al., 2009) } \\
\text { - By 2050s, London will experience } \\
\text { temperatures above the Met Office's } \\
\text { current heatwave temperature } \\
\text { threshold for one third of summer } \\
\text { months (LCCP, 2012) }\end{array}$ & $\begin{array}{l}\text { - Buckling events to become four-five } \\
\text { times more likely by 2050s (Jenkins et } \\
\text { al., 2012) } \\
\text { - For above ground network, sagging of } \\
\text { overhead lines and overheating of } \\
\text { lineside electronic equipment (Network } \\
\text { Rail, 2015) }\end{array}$ \\
\hline
\end{tabular}




\begin{tabular}{|c|c|c|}
\hline & & $\begin{array}{l}\text { - For underground rail, increased need for } \\
\text { air conditioning systems and ventilation } \\
\text { problems within tunnels (Baker at. al, } \\
\text { 2010) } \\
\text { - Temperatures exceeding } 40^{\circ} \mathrm{C} \text { on } \\
\text { London Underground are expected to } \\
\text { rise due to projected increased daily } \\
\text { mean temperature and UHI effect (Arkell } \\
\text { and Darch, 2006; Jenkins et al., 2014) }\end{array}$ \\
\hline Drought & $\begin{array}{l}\text { - Between } 2010 \text { and } 2012 \text { many parts } \\
\text { of Southeast England experienced } \\
\text { lowest } 18 \text {-month rainfall totals in over } \\
100 \text { years (Cabinet Office, 2017) } \\
\text { - Increase in winter and summer } \\
\text { temperatures likely to exacerbate } \\
\text { drought risk (CCC, 2016) London } \\
\text { may experience a water deficit of } \\
10 \% \text { by } 2025 \text {, increasing up to } 21 \% \\
\text { by } 2040 \text { (Future of London, 2016) }\end{array}$ & $\begin{array}{l}\text { - Increases risk of shrink-swell behaviour, } \\
\text { resulting in earthworks issues (Clarke } \\
\text { and Smethurst, 2010) and subsequent } \\
\text { failure of lineside equipment foundations } \\
\text { (Heniz-Peter, 2017) } \\
\text { - Increase likelihood/severity of desiccation } \\
\text { of embankments leading to a higher } \\
\text { number of failures (Glendinnings et al., } \\
\text { 2014; Baker at. al, 2010) }\end{array}$ \\
\hline
\end{tabular}

\subsection{Climate resilient rail infrastructure}

Resilience can be defined as "the ability of a system, community or society exposed to hazards to resist, absorb, accommodate, adapt to, transform and recover from the effects of a hazard in a timely and efficient manner..." (UNISDR, 2017, p. ni). Resilience is a multi-faceted concept that can have many different applications and uses (Alexander, 2013); one of these is within the subject of infrastructure. The Department for Transport (DfT, 2014) breaks down infrastructure resilience into three layers: physical resilience of transport systems; restoration of services after process/procedural failures; and effective communication to minimise disruption to users. Whilst layers two and three consider the response and recovery of the network, layer one focuses on the resistance (strength/protection to resist hazards), reliability (guaranteed operation during extreme events) and redundancy (additional capacity during an emergency) of infrastructure, which are delivered through the high-quality design of the associated networks and systems (Cabinet Office, 2011).

As existing rail assets have often been built for a past climate, approaches such as retrofitting or changing maintenance regimes are required to minimise weather-related vulnerabilities; in contrast, new infrastructure needs to be designed and constructed carefully so it can operate under a future climate for its entire lifetime (Defra, 2011). Major transport routes (e.g. Crossrail) are built to lifetimes in excess of 100 years, meaning they would be more at risk from future changes in climate and therefore must have a greater level of resilience built into them than other infrastructure projects (Defra, 2011).

National and local government can play a vital role in improving climate resilience through the creation of CCA policies and frameworks, and providing the private sector with continued information through sectoral adaptation plans (Defra, 2013). Infrastructure owners/operators/managers also have an important role in ensuring infrastructure is climate resilient, as they can integrate CCA into the maintenance of existing infrastructure and ensure resilience measures are incorporated into new infrastructure projects (Defra, 2013). Current and future rail project organisations therefore have the opportunity to embed climate resilience in the planning, design and construction phases - this can be 
achieved by involving a wide range of stakeholders (Bosher et al., 2007), and through two main options: resilience measures (e.g. defenses to reduce flood risk, adequate air-conditioning/ventilation systems to prevent overheating), and design standards (e.g. BS EN 50125 'Environmental conditions for equipment in railway applications').

\subsection{Defining a multi-hazard approach}

The concept of a multi-hazard (or all-hazards) approach involves addressing the resilience of an environment to the multiple hazards that are present, rather than only single hazards (Ford et al., 2015). United Nations General Assembly (2016, p. 19) defines multi-hazard as "the specific contexts where hazardous events may occur simultaneously or cumulatively over time, taking into account the potential interrelated effects" - thus hazards are not always independent. Budimir et al. (2016) outline four types of hazard interactions:

- One hazard triggering one or more secondary hazard events (e.g. earthquake triggering a landslide);

- A series of triggering relationships forming a cascade/domino event (e.g. earthquake triggering a landslide, damming a river, resulting in flooding);

- One hazard changing the probability of an event occurring (e.g. wildfire removing vegetation, increasing the probability of landslides in the event of a major rainstorm);

- The spatial/temporal coincidence of natural hazards, resulting in an impact greater than the sum of its component parts.

A multi-hazard approach and its practical and local applications are not covered extensively in literature; although some frameworks for assessing interrelated hazards have been developed by researchers, such as Mignan et al. (2014) and Gill and Malamud (2014). The latter characterised and visualised the interactions between twenty-one different natural hazards, focusing on the instances where one hazard may trigger or increase the likelihood of a secondary hazard occurring. Although these global methods do not consider the local context for multi-hazard scenarios, they provide policymakers with key information pertaining to the risks associated with multi-hazard events (Duncan et al., 2016). Most assessments described as multi-hazard do not take into account the interactions of hazards, instead considering multiple hazards at any given place but at different times, with the aim to prioritise those hazards (Duncan et al., 2016). Chmutina et al. (2017) state that a multi-hazard approach should address a range of hazards across both spatial and temporal scales; without this, the effect of one hazard might intensify the effect of another, thereby producing a 'complex/compound hazard'. According to Duncan et al. (2016), failing to take into account hazard interactions may underestimate risk and increase vulnerability.

In a UK context, the Natural Hazards Partnership have outlined plans to develop Hazard Impact Models (HIMs); these models will support a consistent method for assessing the risks of natural hazards, with opportunities arising to combine them to create multi-hazard HIMs (Hemingway and Gunawan, 2018). UK government signed up to the Sendai Framework for DRR and is therefore responsible for implementing its actions (UNSIDR, 2018). One of the 'guiding principles' of the framework is for "decision-making to be inclusive and risk informed while using a multi-hazard approach [...] within and across all sectors" (UNISDR, 2015, p. 36, authors' emphasis). This highlights the global stance on 
ensuring a multi-hazard approach is used sector-wide; it should thus be considered in the context of London's rail infrastructure.

\section{Methodology}

In order to explore the extent to which climate resilience is being embedded in rail infrastructure projects in London through use of a multi-hazard approach, three steps have been taken.

Firstly, a literature review examined and critiqued a number of sources, including: academic papers, books, industrial and institutional reports, and government documents. Secondly, in-depth content analysis of: national (Defra) and local (GLA) government policy documents; rail infrastructure owners/managers/operators reports; and industry reports - only the most recent (2011-2018) and prominent documents were analysed. Thirdly, twelve 40-minute semi-structured interviews were conducted in February - March 2018 with a range of key stakeholders, including: climate experts, national/local government policymakers, CCA managers, rail industry professionals, and a researcher (with multi-hazard research expertise). Sources utilised to locate appropriate individuals included literature review documents, published meeting minutes and recommendations from industry and government contacts. Despite all interviewees holding appropriate roles for the research scope (increasing reliability), generalisations have been avoided throughout the discussion. Collected data was thematically analysed as it allowed for the identification of themes, whilst exploring connections that emerge across the themes (Aronson, 1995).

\section{Results and Discussion}

The analysis of documents and interviews identified that whilst explicit use of a multi-hazard approach is still lacking, it is critical to enhance the understanding of why such an approach should be considered during the planning/design of major UK infrastructure projects (specifically London's rail infrastructure). Table 2 provides an overview of the results obtained during the interviews; whilst the following subsections discuss the key messages that emerged from the analyses.

Table 2. Overview of interviewees' opinions on climate-induced threats and a multi-hazard approach (MHA)

\begin{tabular}{|l|l|l|l|}
\hline $\begin{array}{l}\text { Interviewees' } \\
\text { professional } \\
\text { expertise / Theme }\end{array}$ & $\begin{array}{l}\text { Key climate - induced } \\
\text { hazards that impact } \\
\text { rail infrastructure }\end{array}$ & $\begin{array}{l}\text { General } \\
\text { understanding/ } \\
\text { perception of multi- } \\
\text { hazard approach } \\
\text { (MHA) }\end{array}$ & $\begin{array}{l}\text { Key components that } \\
\text { would be required for } \\
\text { a multi-hazard } \\
\text { approach }\end{array}$ \\
\hline Policymaking & $\begin{array}{l}\text { Flooding } \\
\text { Storms } \\
\text { Extreme temperatures }\end{array}$ & $\begin{array}{l}\text { little } \\
\text { understanding; would } \\
\text { require a cost-benefit } \\
\text { analysis to see whether } \\
\text { it should be better addressing the } \\
\text { implemented }\end{array}$ & $\begin{array}{l}\text { Better coordination with } \\
\text { risks to existing } \\
\text { infrastructure; } \\
\text { climate experts and } \\
\text { researchers; } \\
\text { Enhanced } \\
\text { understanding of single }\end{array}$ \\
\hline
\end{tabular}




\begin{tabular}{|c|c|c|c|}
\hline & & & $\begin{array}{l}\text { hazards prior to multi- } \\
\text { hazard awareness } \\
\text { raising }\end{array}$ \\
\hline $\begin{array}{l}\text { Infrastructure/ } \\
\text { engineering }\end{array}$ & $\begin{array}{l}\text { Flooding } \\
\text { Extreme temperatures }\end{array}$ & Basic understanding & $\begin{array}{l}\text { Long-term thinking; } \\
\text { MHA mainstreamed } \\
\text { into development } \\
\text { processes. }\end{array}$ \\
\hline $\begin{array}{l}\text { Climate change } \\
\text { adaptation }\end{array}$ & $\begin{array}{l}\text { Flooding } \\
\text { Drought } \\
\text { Extreme temperatures } \\
\text { Storms } \\
\text { Landslides (as a } \\
\text { secondary hazard) }\end{array}$ & $\begin{array}{l}\text { No understanding to } \\
\text { basic understanding of } \\
\text { practice application but } \\
\text { perceived to be useful }\end{array}$ & $\begin{array}{l}\text { Enhanced knowledge } \\
\text { among the policy } \\
\text { makers of CC; } \\
\text { Better partnerships and } \\
\text { collaborations among } \\
\text { industry, policy makers } \\
\text { and research; }\end{array}$ \\
\hline Research & $\begin{array}{l}\text { Flooding } \\
\text { Extreme temperatures }\end{array}$ & $\begin{array}{l}\text { Some understanding; } \\
\text { requires more attention } \\
\text { to interdependencies } \\
\text { and interactions } \\
\text { between hazards at } \\
\text { different scales }\end{array}$ & $\begin{array}{l}\text { Climate change } \\
\text { adaptation should be } \\
\text { mainstreamed into } \\
\text { large infrastructure } \\
\text { projects; } \\
\text { Better understanding of } \\
\text { the hazards' impacts } \\
\text { on a larger scale; } \\
\text { Better engagement of } \\
\text { key government } \\
\text { agencies in driving the } \\
\text { agenda }\end{array}$ \\
\hline Railway & $\begin{array}{l}\text { Flooding } \\
\text { High wind } \\
\text { Extreme temperatures } \\
\text { Landslides }\end{array}$ & $\begin{array}{l}\text { Some understanding } \\
\text { but largely conceptual } \\
\text { (e.g. mentioned in } \\
\text { policies but not applied } \\
\text { in practice) }\end{array}$ & $\begin{array}{l}\text { Better awareness of } \\
\text { impacts of CC among } \\
\text { the construction and } \\
\text { infrastructure sector; } \\
\text { MHA should be } \\
\text { incorporated early into } \\
\text { the concept/ design } \\
\text { stages of a project; } \\
\text { Change in long- term } \\
\text { thinking; }\end{array}$ \\
\hline
\end{tabular}

\subsection{Considering the full range of climate-induced hazards}

As discussed previously, London is prone to a number of climate-induced hazards, with interviews highlighting that the highest priority hazards are flooding, extreme heat and drought; and suggesting that extreme cold, storms and gales are not viewed as critical to London's future protection. Interviewees 
identified a difference between the major climate risks for London, and those for the city's rail infrastructure. The rail industry representatives identified pluvial flooding and extreme heat as the major climate-induced hazards; these are expected to increase in frequency/severity in the future, and were the focus of the project reports analysed - although these were viewed as two separate climate risks (i.e. not interrelated). A CCA Manager believed that extreme temperatures (including cold/frost) provide one of the greatest risks to the rail network; however, this interviewee said that due to current projections, hot/dry weather and rainfall will be of high priority, overtaking cold weather (despite extreme events still projected to occur).

There is uncertainty surrounding some climate-induced hazards (e.g. future wind speeds), potentially why interviewees viewed these as less threatening to London. Two interviewees (research manager and CCA infrastructure planner) suggested organisations often focus on the key hazards that are highlighted in national/local government reports/guidance - implying that without legislation/policies emphasising the need to consider a wide range of climate-induced hazards, certain weather types (e.g. extreme cold) are often overlooked. For example, interviews highlighted that UKCP09 is used by a wide range of decision makers as a key source of climate data; consequently, due to complexities associated with projecting certain climate-induced hazards and the interactions between them, these aspects of climate resilience (and more specifically a multi-hazard approach) may well be neglected. One interviewee (a researcher) highlighted that by adopting a multi-hazard approach in its most basic form, industry professionals should at the very least be considering the full range of climate-induced hazards that could be faced. This research suggests that the extent to which this is being done in current projects is unclear. Although it will be difficult to create multi-hazard climate projections in the future as too many variables are involved, they still have a role to play in informing decisions.

\subsection{Building climate resilience into the pre-construction phase through stakeholder partnerships}

Interviews emphasised the need to consider all possible scenarios and extremes now, and where this is not possible, build a degree of flexibility into projects to allow for adaptive capacity. A rail industry professional explained that it is extremely difficult to change a design once new climate data has been made available, highlighting the need to consider all possible climate projections when designing new rail projects, to ensure that solutions can mitigate climate-induced hazards throughout the entire operational phase of the railway. This is particularly important when considering a multi-hazard environment, as it may become even more difficult to adapt aspects of a project post-construction.

A range of organisations play a part in building the resilience of new rail projects - a key interview finding was the need for organisations to work together during the planning/design phase of major projects, particularly when considering hazard interactions. The Department for Environment, Food and Rural Affairs (Defra, 2011) advises that collaborative working between industry professionals and policymakers will ensure vital information and best practice methods are shared across a range of sectors. One interviewee (climate expert) believes it "requires a partnership approach in order to make sure people are staying strategic and seeing the links and opportunities for CCA" - one of these 'opportunities' is the consideration of a multi-hazard approach to identify the additional future climate risks major projects may face. Therefore, it makes sense for key stakeholders to pursue a platform to ensure joined-up thinking in order to create a shared vision for use of such an approach within new rail 
projects. The use of existing mechanisms, such as industry forums and research initiatives, would provide a recognized platform to raise awareness and develop understanding. For example, the Natural Environment Research Council (NERC) led the 'Environmental Risks to Infrastructure Innovation Programme' (ERIIP), which brought together a range of infrastructure stakeholders to discuss key themes - one was the "likelihood, effect and impact of multi-hazard combinations on the infrastructure system" (NERC, 2018, p. ni), thus highlighting the applicability of multi-hazards to infrastructure sectors.

\subsection{Limited understanding of multi-hazard approach}

This research showed that a multi-hazard approach is a new concept to decision makers in the rail industry; ten interviewees had either not heard of or had limited understanding of the approach (i.e. did not consider hazard interactions). Having explained a multi-hazard approach, those interviewees displayed a high-level of interest - including recognition of how it might be used by their organisations - and believed it could be relevant for both the UK and more specifically, rail infrastructure.

An interviewee (researcher) identified a number of potential hazard interactions that the UK may experience (such as heatwaves and droughts occurring simultaneously), and believed that they had the potential to pose a threat to rail infrastructure, especially when consideration was given to how the frequency/severity of climate-induced hazards may change in the future as a result of climate change. Interestingly, a CCA manager highlighted that government officials and infrastructure planners are now talking about multi-hazard events; this contrasted with the responses given by government policymakers who were not aware of the approach. Although it was noted that the sample of government officials interviewed was small, their roles within their respective department and their involvement with CCA suggests that if it was on the government's radar, they would have heard of it.

\subsection{More research into multi-hazard approach required}

Whilst some research already exists (e.g. TRaCCA project), a recurring theme highlighted that a multihazard approach still requires research and development in order for it to be implemented into new rail projects. For example, one interviewee stated that "it's an area where I think the underlying research still needs to be developed", and that very little research has been done into hazard interactions, especially in an infrastructure context. They believed that research needed in the UK involves modelling the likely magnitude of hazard interactions and looking into the probability of hazards increasing the likelihood of other events occurring, thus suggesting that the research required is more climate-focused than infrastructure-specific. A CCA manager outlined that a multi-hazard approach is being talked about but there's no official guidance - they said "we are in the place where the theory is sound but the practice is not mature, we need to have a better understanding of how real this problem is".

Little evidence suggests that a multi-hazard approach is mainstreamed in considerations for the planning/design of rail infrastructure. Whilst research focusing on multi-hazard resilience and interdependencies of infrastructure networks has been explored by industry in recent years (e.g. research projects supported by HS2, DfT, etc.), seemingly, most current practice addresses single independent hazards. However, the ways of considering multi-hazards exist: Environment Agency flood risk maps look at multiple hazard events, such as the spatial/temporal effects of multiple floods 
occurring; also, desiccation and slope stability for embankments/earthworks is a multi-hazard problem. The only document analysed that mentioned either the use of a multi-hazard approach or the threat of hazard interactions on rail assets was the Rail Safety and Standards Board report (RSSB, 2016). A medium term (5-15 years) recommendation to the rail industry was: "establish how combined or sequential weather events or conditions impact asset degradation and performance, and consider how these events and impacts are projected to change in the future as a result of climate change" (RSSB, 2016, p. 12). A number of examples were provided, in terms of researching the impacts of: multiple rainfall events, soil desiccation followed by heavy rain, and flood risk exacerbated by melting snow. As the report outlined that research into multi-hazards was required, it is unlikely that current rail projects are addressing this issue. This was confirmed by an industry professional, who said their organisation had only recently commissioned research into the effect of multiple combined hazards on earthworks.

\subsection{Opportunities to address multi-hazard approach within London's rail projects}

With greater understanding of how single independent hazards affect rail assets and how resilience measures can reduce climate risk, there is an opportunity for industry professionals to assess the vulnerability of assets to multi-hazard environments, which may be an increasingly important aspect of climate change. An interviewee (researcher) identified an opportunity for the rail industry, through creating multi-hazard scenarios to assess the risk: "I think in terms of the potential for there to be a chain of hazards that affect the network, then it would be identifying possible scenarios where that could occur, and the relative likelihood". They added that there were some basic elements that could be addressed now, such as systematic identification of possible climate-induced hazards that could occur and expert discussion on this (in a UK context), and felt the concept could be progressively introduced into the rail sector to develop understanding, rather than wait for policies, due to the voluntary nature of CCA activity in the UK.

In the short-term (without a multi-hazard framework), one interviewee suggested new projects could go through a process of trial and error to see what works; designers may have to "develop [solutions] on the hoof' in order to mitigate multi-hazard risks. As a minimum requirement, organisations should not disregard a multi-hazard approach in its entirety and instead look to identify if and how it could be incorporated into the thinking process when developing new rail projects.

\subsection{Recommendations}

In order to raise awareness of hazard interactions and understand whether a multi-hazard approach could be incorporated into the design of new rail projects, two main stages must be considered. Firstly, more research is required as to how/what multi-hazard scenarios could affect the UK (Route 1) involving: 1) identifying which climate-induced hazards can viably interact with each other; 2) understanding the effect of these hazard interactions in terms of their cumulative result; and 3) determining the impact this may have on the UK (in a locational context). A collaborative approach between climate experts and hazard specialists (e.g. flooding, drought, etc.) is needed in order to cross-reference the different hazards and comprehend how this may change in the future due to current climate projections - a similar approach to the NERC ERIIP workshops (with more focus on climate/hazard professionals as opposed to infrastructure stakeholders). Once multi-hazard events (e.g. long period of drought followed by intense rainfall) have been identified and frameworks for assessment clarified, an exploration into how 
these events may impact on different aspects of the rail network is required (Route 2). This would involve practitioners from Route 1 working together with rail experts to identify additional vulnerabilities that may arise due to these multi-hazard events. For example, workshops could be set up between multi-hazard practitioners and geotechnical engineers to assess whether certain events may exacerbate the climate risks facing embankments in the future. Rail organisations would then have the opportunity to undertake detailed research programmes in order to understand the potential impacts of multi-hazard events on specific rail assets.

Before a more formal multi-hazard framework has been agreed, conceptual research into the approach could be part of an evidence-based programme of resilience measures. Rail infrastructure owners/managers could lead expert discussions in collaboration with climate experts, rail industry professionals, etc., whilst running pilot studies to explore the value of using a multi-hazard approach to build climate resilience of current rail projects, resulting in possible detection of multi-hazard vulnerabilities.

\section{Conclusions}

This paper demonstrated that decision makers within the rail industry have a limited understanding of a multi-hazard approach; although they showed high-level interest when the method was explained. As current projections suggest the UK will be increasingly affected due to a rise in the frequency/severity of a range of climate-induced hazards, there is significant potential that multiple hazards will occur at the same time and in the same location, thus exacerbating climate risk. Despite official guidance suggesting otherwise, it is important that decision makers consider the full range of climate-induced hazards that affect London, particularly the impact of extreme weather events - a key aspect of a multihazard approach. However, the rail industry must take a holistic approach to considering multi-hazards, as disregarding the complexity of and interactions between different climate-induced hazards will widen vulnerabilities and create more long-term risks.

Although some research has been commissioned into multi-hazard events and their effects on specific rail assets - highlighting its practical relevance within infrastructure planning/design - there is little evidence that shows whether and how it has been utilised by decision makers for current rail projects.

Opportunities have been identified to increase awareness: more research is required in order to effectively educate, influence and persuade organisations and decision makers to consider the prospect of multi-hazard events in the future through creation of stakeholder partnerships.

There is a clear argument that supports the use of a multi-hazard approach to address the interrelations between climate-induced hazards and mitigate potential vulnerabilities of rail assets in London. Due to the increasing risks associated with climate change, it would be irresponsible of decision makers to not consider the likelihood and severity of such events occurring in the future and the potential impacts, especially considering the amount of public money used to fund major rail projects and the $100+$ year lifetimes these projects are built to.

\subsection{Practical relevance and potential applications}

The paper has identified that a multi-hazard approach is relevant for current rail projects; therefore, the onus is on key stakeholders within the rail industry to research its applications and provide opportunities 
for discussions to take place. Ultimately, following the recommendations outlined in Section 4.6 will allow decision makers to understand whether a multi-hazard approach should be considered during the planning/design of London rail projects; only then could specific policies and guidance relating to a multihazard approach be published.

It must also be noted that although the focus of this paper was on current and future rail projects in London, the use of a multi-hazard approach is applicable to all infrastructure sectors across the UK, as highlighted in the Sendai Framework for DRR. Therefore, the recommendations provided are relevant to a greater range of decision makers than the context of the paper outlines - particularly determining the likelihood/severity of multi-hazard events in the future (Route 1) - with practical applications to be explored by the wider civil engineering industry.

\section{References}

Alexander DE (2013) Resilience and disaster risk reduction: an etymological journey. Natural Hazards Earth System Sciences 13(11): 2707-2716, http://doi.org/10.5194/nhess-13-2707-2013.

Arkell B and Darch G (2006) Impact of climate change on London's transport network. Proceedings of the Institution of Civil Engineers - Municipal Engineer 159(4): 231-237,

http://doi.org/10.1680/muen.2006.159.4.231.

Armstrong J, Preston J and Hood I (2017) Adapting railways to provide resilience and sustainability. Proceedings of the Institution of Civil Engineers - Engineering Sustainability 170(4): 225-234, http://doi.org/10.1680/jensu.15.00017.

Aronson J (1995) A Pragmatic View of Thematic Analysis. The Qualitative Report 2(1): 1-3, http://nsuworks.nova.edu/tgr/vol2/iss1/3.

Arup (2014) Reducing urban heat risk: A study on urban heat risk mapping and visualisation. Arup, London, UK. See http://www.arup.com/-

/media/arup/files/publications/r/reducing_urban_heat_risk_full_report.pdf (accessed 10/12/2017).

Baker CJ, Chapman L, Quinn A and Dobney K (2010) Climate change and the railway industry: A review. Proceedings of the Institution of Mechanical Engineers: Part C Journal of Mechanical Engineering Science 224(3): 519-528, http://doi.org/10.1243/09544062jmes1558.

Bosher L, Dainty A, Carillo P and Glass J (2007) Built-in resilience to disasters: a pre-emptive approach. Engineering Construction and Architectural Management 14(5): 434-446, http://doi.org/10.1108/09699980710780746.

BSI (British Standards Institution) (2003) EN 50125-3:2003. Railway applications. Environmental conditions for equipment. Equipment for signalling and telecommunications. BSI, London, UK.

Budimir M, Duncan M and Gill JC (2016) The Dynamic and Impact of Interacting Natural Hazards: Background. Interacting Hazards. See http://www.interactinghazards.com/Interacting-HazardsResearch (accessed 18/12/2018). 
Cabinet Office (2011) Keeping the Country Running: Natural Hazards and Infrastructure: A Guide to improving the resilience of critical infrastructure and essential services. Cabinet Office, London, UK. See http://www.gov.uk/government/uploads/system/uploads/attachment_data/file/61342/naturalhazards-infrastructure.pdf (accessed 18/12/2018).

Cabinet Office (2017) National Risk Register of Civil Emergencies: 2017 edition. Cabinet Office, London, UK. See

http://www.gov.uk/government/uploads/system/uploads/attachment_data/file/419549/20150331_2015NRR-WA_Final.pdf (accessed 18/12/2018).

Chmutina K, Jigyasu R and Bosher L (2017) Integrating DRR including CCA into the delivery and management of the built environment. In The Routledge Handbook of Disaster Risk Reduction Including Climate Change Adaptation (Kelman I, Mercer J and Gaillard JC (ed.)). Routledge, Oxon, UK, pp. 264-274.

Clarke D and Smethurst J (2010) Effects of climate change on cycles of wetting and drying in engineered clay slopes in England. Quarterly Journal of Engineering Geology and Hydrogeology 43(4): 473-486, http://doi.org/10.1144/1470-9236/08-106.

Climate Change Act 2008 (2008) Elizabeth II. Chapter 27. Her Majesty's Stationery Office, London, UK.

CCC (Committee on Climate Change) (2014) Managing climate risks to well-being and the economy: Adaptation Sub-Committee Progress Report 2014. CCC, London, UK. See

http://www.theccc.org.uk/wp-content/uploads/2014/07/Final_ASC-2014_web-version-4.pdf (accessed 18/12/2018).

CCC (2016) UK Climate Change Risk Assessment 2017: Synthesis Report. CCC, London, UK. See http://www.theccc.org.uk/wp-content/uploads/2016/07/UK-CCRA-2017-Synthesis-Report-Committeeon-Climate-Change.pdf (accessed 18/12/2018).

Davoudi S, Mehmood A and Brooks L (2011) The London Climate Change Adaptation Strategy: Gap Analysis. Global Urban Research Unit: Electronic Working Paper Series 44(2011): 1-62, http://orca.cf.ac.uk/id/eprint/53010.

Dawson RJ, Thompson D, Johns D et al. (2016) UK Climate Change Risk Assessment Evidence Report: Chapter 4, Infrastructure. Adaptation Sub-Committee of the Committee on Climate Change, London, UK. See http://www.theccc.org.uk/wp-content/uploads/2016/07/UK-CCRA-2017-Chapter-4Infrastructure.pdf (accessed 18/12/2018).

Defra (Department for Environment, Food and Rural Affairs) (2011) Climate Resilient Infrastructure: Preparing for a Changing Climate. Defra, London, UK. See http://www.gov.uk/government/uploads/system/uploads/attachment_data/file/69269/climate-resilientinfrastructure-full.pdf (accessed 18/12/2018). 
Defra (2013) The National Adaptation Programme: Making the country resilient to a changing. Defra, London, UK. See

http://www.gov.uk/government/uploads/system/uploads/attachment_data/file/209866/pb13942-nap20130701.pdf (accessed 18/12/2018).

DfT (Department for Transport) (2014) Transport Resilience Review: A review of the resilience of the transport network to extreme weather events. DfT, London, UK. See http://www.gov.uk/government/uploads/system/uploads/attachment_data/file/335265/transportresilience-review-print.pdf (accessed 18/12/2018).

DfT (2017). Rail Factsheet. DfT, London, UK. See http://www.gov.uk/government/uploads/system/uploads/attachment_data/file/663116/rail-factsheet2017.pdf (accessed 18/12/2018).

Duncan M, Edwards S, Kilburn C, Twigg J and Crowley K (2016) Case Study F: An Interrelated Hazards Approach to Anticipating Evolving Risk. In The making of a riskier future: How our decisions are shaping future disaster risk (Global Facility for Disaster Reduction and Recovery), pp. 114-121 See http://www.gfdrr.org/sites/default/files/publication/Riskier\%20Future.pdf (accessed 18/12/2018).

Ford A, Pregnolato M, Jenkins K, Barr S and Dawson R (2015) Assessing the need for infrastructure adaptation by simulating impacts of extreme weather events on urban transport infrastructure. In Proceedings of the GISRUK 2015 (Malleson N, Addis N, Durham, H et. Al (eds.)), pp. 175-182. See http://doi.org/10.6084/m9.figshare.1491375 (accessed 18/12/2018).

Forzieri G, Bianchi A, Batista e Silva F, Marin Herrera MA, Leblois A, Lavalle C, Aerts JCJH, Feyen L (2018) Escalating impacts of climate extremes on critical infrastructures in Europe. Global Environmental Change 2(2018): 97-107, https://doi.org/10.1016/j.gloenvcha.2017.11.007.

Future of London (2016) Managing London's Exposure to Climate Change. Future of London, London, UK. See http://www.futureoflondon.org.uk/publications/ (accessed 18/12/2017).

Gill JC and Malamud BD (2014) Reviewing and visualizing the interactions of natural hazards. Review of Geophysics 52(2014): 1-43, http://doi.org/10.1002/2013RG000445.

GLA Intelligence (2017) 2016-based Trend Projection Results: Update 2017-09. GLA, London, UK. See http://www.london.gov.uk/sites/default/files/2016_based_trend_projection_results.pdf (accessed 18/12//2018).

Glendinning S, Hughes P, Helm PR et al. (2014) Construction, management and maintenance of embankments used for road and rail infrastructure: implications of weather induced pore water pressures. Acta Geotechnica 9(5): 799-816, http://doi.org/10.1007/s11440-014-0324-1.

Greater London Authority Act 2007 (2007) Elizabeth II. Chapter 24. Her Majesty's Stationery Office, London, UK. 
GLA (Greater London Authority) (2015) London Sustainable Drainage Action Plan. GLA, London, UK. See http://www.london.gov.uk/sites/default/files/lsdap_december_2016.pdf (accessed 18/12/2018).

Hansford P (2016) People: in focus - Professor Peter Hansford on the reasons for HS2. University College London, London, UK. See http://www.ucl.ac.uk/bartlett/construction/news/2016/dec/peoplefocus-professor-peter-hansford-reasons-hs2 (accessed 18/12/2018).

Heinz-Peter B (2017) Risks and consequences of weather hazards on railway infrastructure. Journal of Polish Safety and Reliability Association 8(1): 1-12, http://jpsra.am.gdynia.pl/archives/jpsra-2017contents/.

Hemingway R and Gunawan O (2018) The Natural Hazards Partnership: A public-sector collaboration across the UK for natural hazard disaster risk reduction. International Journal of Disaster Risk Reduction 27(2018): 499-511, http://doi.org/10.1016/j.ijdrr.2017.11.014.

House of Commons (2010) Keeping the UK moving: The impact on transport of the winter weather in December 2010: 5th Report of Session 2010-12, Volume II. House of Commons Transport Committee, London, UK. See http://publications.parliament.uk/pa/cm201012/cmselect/cmtran/794/794vw.pdf (accessed 18/12/2018).

ICE (Institution of Civil Engineers) (2009) The State of the Nation: Defending Critical Infrastructure. ICE, London, UK. See http://www.ice.org.uk/getattachment/news-and-insight/policy/state-of-thenation-critical-infrastructure-2009/SoN_DCIreport_final_web.pdf.aspx (accessed 18/12/2018).

ICE (2017) Preparing London for Change: Lecture 2 - Natural threats. ICE, London, UK. See http://www.ice.org.uk/eventarchive/preparing-london-for-change-lecture-2-london (accessed 18/12/2018).

IPCC (Intergovernmental Panel on Climate Change) (2013) Climate Change 2013: The Physical Science Basis. Contribution of Working Group I to the Fifth Assessment Report of the Intergovernmental Panel on Climate Change. IPCC, Geneva, Switzerland. See http://www.climatechange2013.org/images/report/WG1AR5_ALL_FINAL.pdf (accessed 18/12/2018).

IPCC (2014) Climate Change 2014: Synthesis Report. Contribution of Working Groups I, II and III to the Fifth Assessment Report of the Intergovernmental Panel on Climate Change. IPCC, Geneva, Switzerland. See http://ipcc.ch/pdf/assessment-report/ar5/syr/SYR_AR5_FINAL_full_wcover.pdf (accessed 18/12/2018).

Jenkins GJ, Murphy JM, Sexton DMH et al. (2009) UK Climate Projections: Briefing Report. Met Office Hadley Centre, Exeter, UK. See http://ukclimateprojections.metoffice.gov.uk/media.jsp?mediaid=87868\&filetype=pdf (accessed 18/12/2018). 
Jenkins K, Glenis V, Ford A and Hall J (2012) A Probabilistic Risk-Based Approach to Addressing Impacts of Climate Change on Cities: The Tyndall Centre's Urban Integrated Assessment Framework. UGEC Viewpoints 8(2012): 8-11, http://eprint.ncl.ac.uk/198142.

Jenkins K, Gilbey M, Hall J, Glenis V and Kilsby C (2014) Implications of climate change for thermal discomfort on underground railways. Transportation Research Part D: Transport and Environment 30(2014): 1-9, http://doi.org/10.1016/j.trd.2014.05.002.

LCCP (London Climate Change Partnership) (2012) A Summary of Climate Change Risks for London. LCCP, London, UK. See http://climatelondon.org/wp-content/uploads/2017/11/CCRA-London.pdf (accessed 18/12/2018).

LRP (London Resilience Partnership) (2016) London Risk Register 2016. LRP, London, UK. See http://www.london.gov.uk/sites/default/files/london_risk_register_6.0.pdf (accessed 18/12/2018).

Mignan A, Wiemer S and Giardini D (2014) The quantification of low-probability-high-consequences events: part I. A generic multi-risk approach. Natural Hazards 73(3): 1999-2022, https://doi.org/10.1007/s11069-014-1178-4.

Murphy J, Sexton D, Jenkins G et al. (2010) UK Climate Projections science report: Climate change projections. Met Office Hadley Centre, Exeter, UK. See

http://ukclimateprojections.metoffice.gov.uk/media.jsp?mediaid=87893 (accessed 18/12/2018).

NERC (Natural Environment Research Council) (2018) Environmental Risks to Infrastructure Innovation Programme. NERC, Swindon, UK. See

https://nerc.ukri.org/innovation/activities/infrastructure/envrisks/\#xcollapse7 (accessed 18/12/2018).

Network Rail (2014) Route Weather Resilience and Climate Change Adaptation Plans: South East. Network Rail, London, UK. See http://cdn.networkrail.co.uk/wp-content/uploads/2016/11/South-EastRoute-WRCCA-Plan.pdf (accessed 18/12/2018).

Network Rail (2015) Climate Change Adaptation Report. Network Rail, London, UK. See http://www.networkrail.co.uk/wp-content/uploads/2016/11/Climate-Change-Adaptation-Report2015_FINAL.pdf (accessed 18/12/2018).

Oke TR (1973) City size and the urban heat island. Atmospheric Environment 7(8): 769-779, http://doi.org/10.1016/0004-6981(73)90140-6.

RSSB (Rail Safety and Standards Board) (2016) Tomorrow's Railway and Climate Change Adaptation: Final Report. RSSB, London, UK. See http://www.sparkrail.org/_layouts/15/Rssb.Spark/Attachments.ashx?Id=75NEMTS3ZVHP-8-12169 (accessed 18/12/2018).

Sayers PB, Horritt M, Penning-Rowsell E and Mckenzie A (2015) Climate Change Risk Assessment 2017: Projections of future flood risk in UK. Committee on Climate Change, London, UK. See 
http://www.theccc.org.uk/wp-content/uploads/2015/10/CCRA-Future-Flooding-Main-Report-Final06Oct2015.pdf (accessed 18/12/2018).

United Nations General Assembly (2016) Report of the open-ended intergovernmental expert working group on indicators and terminology relating to disaster risk reduction. United Nations General Assembly, Geneva, Switzerland. See

http://www.preventionweb.net/files/50683_oiewgreportenglish.pdf (accessed 18/12/2018).

UNISDR (United Nations Office for Disaster Risk Reduction) (2015) Sendai Framework for Disaster Risk Reduction 2015-2030. UNISDR, Geneva, Switzerland. See

http://www.unisdr.org/files/43291_sendaiframeworkfordrren.pdf (accessed 18/12/2018).

UNISDR (2017) Terminology. UNISDR, Geneva, Switzerland. See

http://www.unisdr.org/we/inform/terminology (accessed 18/12/2018).

UNISDR (2018) Countries \& National Platforms. UNISDR, Geneva, Switzerland. See http://www.unisdr.org/partners/countries (accessed 18/12/2018). 